\title{
Cultural Translation: Comments of Translators in the English Version of the Yakut Epic Olonkho
}

\author{
Alina A. Nakhodkina* \\ M.K. Ammosov North-Eastern Federal University \\ 58 Belinsky Str., Yakutsk, 677000, Russia
}

Received 10.04.2019, received in revised form 25.11.2019, accepted 02.12.2019

The paper outlines questions of functions, typology and origin of the comments of translators as integral part of cultural translation. This study is based on the English translation of the Yakut heroic epic olonkho "Nurgun Botur the Swift" written by P.A. Oyunsky. The author considers the terms 'culture-specific concept', 'lacuna', 'ethnic colour', and 'non-equivalent vocabulary' to be the principal sources of translation comments. The translation comment is a method to transfer and save information, ethnic identity and emotional and expressive functions of the form. Translator not only gives his version of the source text, but also often reconstructs its specific cultural identity. The paper overviews previous publications of the Yakut epic and its translations into Russian and English. The material's singularity and lack of a Yakut-English translation tradition make this study relevant. The case of olonkho can teach us something about the remit of cultural translation. In my research, I defined various practical methods from the English translation of olonkho, including intratextual comments, footnotes, endnotes, and graphical tools of exoticism highlighting.

Keywords: cultural translation, translation comment, culture-specific concept, colour, epic, olonkho, Yakut, English, footnote, italic.

Research area: culturology.

Citation: Nakhodkina, A.A. (2019). Cultural translation: comments of translators in the English version of the Yakut epic olonkho J. Sib. Fed. Univ. Humanit. Soc. Sci., 12(12), 22412257. DOI: $10.17516 / 1997-1370-0519$

\section{Introduction}

The translation of literary works is an essential part of the connection between cultures, but in the process the translator meets with a great number of difficulties. One of the main issues is perception of the foreign-language literary text. In this regard, the modern Russian researcher says, "The main reasons for misunderstanding and

(C) Siberian Federal University. All rights reserved

* Corresponding author E-mail address: aan-2010@yandex.ru ORCID: 0000-0003-1522-2792

This work is licensed under a Creative Commons Attribution-NonCommercial 4.0 International License (CC BY-NC 4.0). 
misreading of the foreign-language literary texts are considered linguistic and nonlinguistic difficulties. In other words, the reason was seen in the text, but not in the communication between the author and the reader. The reason of misreading is to be found not only in the above-mentioned difficulties, but in the reader also. Thus, it is important to focus on the reader, too. It was predicated on the basis that perception of the same text differs: perception of one person corresponds to the author's idea to a greater extent than the other person. It is especially remarkable in perceptions of the native speaker and foreign reader" (Skugarova, 2001: 135).

The translator has to understand and transfer the information as close to the original work as possible, but at the same time, the ethnic and cultural specificity of the text has to be transferred, too. The use of translation comment is one of the most convenient methods in such missions. By the means of translation comment it is possible to transfer colour and expressiveness in the translation. M. Sulaiman emphasizes, that “... culture, or rather cultural differences, have been identified as the main reason behind the failure of translations... Cultural conceptualisation, which is drawn from cultural linguistics, is a key manifestation of the oft-overlooked 'silent' or 'unconscious' level of culture..." (Sulaiman, Wilson, 2018: 629).

The translator not only interprets an original text, but also adapts certain cultural and linguistic phenomena of the source culture. In order to achieve it the translator has to use translation comment since the other methods of translation cannot provide the full information transfer of the original text. The comment is required for the translation of the words and word combinations of the native speakers' background knowledge. The translator has to not only re-create a given text, but also define its involvement in the other culture.

Russian linguist L. Nelyubin in his work "Introduction to techniques of translation" says that based on the receptor's background knowledge, life experience, religion, and other characteristics there might appear the problem of 'translatability and untranslatability' of the text. Y. Vereshchagin and V. Kostomarov acknowledge background knowledge as 'the common ground for the participants of a communication act' (Vereshchagin, Kostomarov, 2005: 126).

According to L. Nelyubin, the problem of translatability is one of the oldest academic problems in the sphere of translation. This problem arises at attempts to define translation requirements. The principle requirements are translation adequacy, accuracy and completeness. Accuracy and completeness of the target language considered to be the basics of translation. They differentiate translation from alterations, paraphrases, 
and abridgements, i.e. other types of adaptation. From our point of view, fundamental translatability is possible. When we talk about peoples with approximately similar levels of culture and scientific and technical development, we can say all thoughts and ideas of one people can be translated into the language of others, i.e. equivalent translation is possible (Nelyubin, 2009: 22-23).

Russian linguist L. Barkhudarov points out that translation comment should not be confused with descriptive translation, which is 'based on defining of the meaning of lexical units of the source language by the means of explicate word combinations, revealing essential characteristics of the lexical unit in the target language'. There are some examples of descriptive translation in the Russian language: landslide победа на выборах с больиим перевесом голосов (an election victory with majority of votes), brinkmanship искусство держать мир на грани войны (the art of holding the world on the verge of war), whistle-stop speech агитационное выступление кандидата во время остановки поезда (candidate's agitation speech made on the train stops) (Barkhudarov, 2008: 99).

\section{Translation comment and its origin}

According to L. Barkhudarov, 'in cases when an appropriate lexical unit in one language for the lexical unit in other language is not available, than in such cases we can talk about non-equivalent vocabulary. The term 'non-equivalent vocabulary' means that one lexical unit (word or set expressions) of the language does not have a complete or partial equivalent lexical unit in the other language (Barkhudarov, 2008: 94).

Culture-specific concepts and lacunae are particular examples of non-equivalent vocabulary and the principle reasons for applying translation comment. The other reason for translation comment use is foreign-language footnotes in the original text. Culture-specific concepts and lacunae are the basics of culture, thus, culture-specific concepts have certain colour. Lacuna (Latin, gap) is a lack of naming object or term in one of the languages, a lexical gap. The first step in translation is to examine the availability of equivalents in the target language. If there is no equivalent, than we are working with lacunae. Lacunae represent the majority of ethnic specificity of every language. Social and political, social and economic, and cultural characteristics of a people, their worldview, psychology, and traditions determine the origin of forms and notions absent in other cultures.

V. Muravyev thinks that lacuna is a word absent in another language (Muravyev, 1975: 96). V. Gak defines lacunae as the gaps in the lexical system of the language, 
which might be available in the language if they are reflected (Gak, 1977: 300). These differing and separating specific ethnic elements in the lexical system of the languages is of certain difficulty for translation as it is the necessity to preserve colour that is the first problem the translator meets. Any nominative unit denoting a certain phenomenon of the culture is known to become the basis of characteristics. For native speakers metaphors and comparisons, based on the phenomena's meaning, may not differ from the other figures of speech, based on terms common to all humankind, such as 'water', 'sun', and 'grass'.

However, the 'exotic images' in the target language are considered to be foreign material for the foreign reader because they either cause misunderstanding or create exaggerated effect. Thus, the translator, driven by the necessity to transfer functional images, aims to find an ultimate solution in every single case. Since in the majority of cases the dominant image function is emotional and expressive, the 'exotic' elements often become bland or exaggerated, so different types of transformations are necessary. Only it is not always possible to preserve a culture-specific concept or substitute it with an equivalent in the other culture. This is especially the case in translation of real and specific associations of a certain subject connected with lexical meaning of the word specificity. For example, in languages that lack culture-specific concepts it is not possible to define equivalent unit of measurement. The translator either makes a substitution or makes a comment on the culture-specific concept. Specific ideas and unique life experience allow native speakers to understand such set expressions; however, their translation is a matter of serious contemplation.

As Jansen states, "The free text comments, however, reveal a more differentiated picture. ...we need to revise some of the traditional dichotomies within translation studies, such as creativity versus fidelity..." (Jansen, 2019: 675).

Translation comment is only used when culture-specific concept / lacuna do not have a certain definition in one language that is available in the other. Translation comment is also used when the translator considers it necessary to explain (in notes, footnotes or parentheses) some of the terms that foreign reader does not know. Comment might be placed:

1) before / after the text;

2) on the foot of a page;

3) in the text after the word requiring explanation.

This especially applies to the transcribed words that might be, in the translator's opinion, unclear to the reader. This is also the case for the translation of proper names. 
Translation comment is often written as an annex in the translation of historic, epic, folklore, and fine arts texts.

\section{The Yakut heroic epic olonkho - a unique cultural phenomenon}

"The topic of ethnic studies of northern peoples" is considered to be up to date, as N. Koptseva states in her article. She also shares her glimpses to "the peculiarity of the cultural Yakut space" telling "Modern Yakutia experiences the most interesting processes of ethnic and cultural identification associated with the active participation of various social groups in cultural processes" (Koptseva, 2019: 1130-1131).

The Yakut folklore tradition is represented by the powerful and colourful genre of heroic epic olonkho. In 2005, olonkho was placed on the list of Masterpieces of the Oral and Intangible Heritage of Humanity of the United Nations Educational, Scientific and Cultural Organization (UNESCO). This new status caused a number of activities in Sakha Republic such as implementation of the Yakut heroic epic olonkho preservation, observation and expansion of a government program and establishment of the NEFU Scientific Research Institute of Olonkho, Theatre of Olonkho, Olonkho Land project, Olonkho information portal, etc.

Yakut researcher I. Pukhov says that olonkho is a common term for the Yakut heroic epic consisting of a collection of legends (Pukhov, 2013: 9). Epic forms of folklore, based in early stage of ethnos, prove that the Russian ethnos was formed at the later stage, so long form oral folklore was lost. The Yakut olonkho is an ancient epic dating back to the times when the Yakut ancestors ('Sakha' is a self-name of the Yakuts) lived in the South and were connected with Turkic and Mongolic tribes living in Altai and Sayans (Pukhov: 2013: 9).

Olonkho was written in an ancient language and was full of symbolic and fanciful images, parallels and complex constructions, traditional poetic forms and vivid expressions (termed 'picturesque words' by famous Yakut writer and philosopher A. Kulakovsky). The language of olonkho is full of different figures of speech, especially metaphors, comparisons, epithets, exaggerations and colourful descriptions. Olonkho's visual symbolism and stylistic devices, detailed poetic language and metaphors are very close to the linguistic perception of the English readers, familiar with Anglo-Saxon poetic tradition of scalds and kennings.

Being the classical example of epic tradition, olonkho demonstrates close connection with the Yakut real life and the genuineness of the events described which 
makes Oyunsky's text a reliable historical and ethnographic source of information about the culture and the history of the Sakha people. Along with the cultural information, an important place in the complicated information continuum of olonkho belongs to cultural memory resulting from mythologization and sacralization of the past of the indigenous Sakha people, being of collective nature and providing the cultural identity of the ethnic group (Razumovskaya, 2018: 363).

Olonkho is an oral genre in which differences between man and woman, and good and evil is achieved by intonation and melody. It was P. Oyunsky who distinguished parts and songs of olonkho and made olonkho easier to read. The most popular storyline is about sky warriors' protection of the Middle World, inhabited by the humankind.

Buryat researcher Y. Hundayeva, who studied an English translation of the "Epic of King Gesar", says that epic text is based on use of metaphorical and associative discourse, so this text is notionally dense and ramous, thus, the translation process causes difficulties. In the pre-translational analysis, we decided to abide by the following guidelines: to make the analysis more convincing; to consider ethnic, historic and geographical characteristics; and to make images more or less easy to understand (Hundayeva, 2016: 205).

\section{Methods}

I considered the issue of translation comment based on the materials of the English translation of P. Oyunsky's fundamental work "Nurgun Botur the Swift" that was done by a team of translators under my supervision at M.K. Ammosov North-Eastern Federal University in Yakutsk. The translation from the Yakut language text was signed off for publishing on 11 October 2013 and published on 2 December 2013 by 'Renaissance Books' Publishing House, however, due to the various organizational aspects the year of publication was 2014 .

It would not have been possible to bring to life this large-scale project without the pure enthusiasm of translators, support of the Yakut Heroic Epic Olonkho Preservation, Observation and Dissemination Government Program (2006-2015) and NEFU Development Program.

This study finds three methods - supplementation, comparison and evaluation - used in the translation comments to reconstruct the unknown Yakut culture. Preparing for translation, I studied the original Yakut text and its Russian translation by V. Derzhavin, the $1^{\text {st }}$ Song translations into English and read various translations in other languages of the olonkho by P. Ogotoyev. I was bewildered by 
the lack of footnotes and comments: their lack makes reading inconvenient and, in my opinion, shows negligence of the translators and publishers. Only I. Pukhov provided the Russian translation with vast comments given at the end of the book. In fact, the original Yakut text never had any comment either, even though the epic style of P. Oyunsky is rather difficult for the modern Yakut readership. As an example, I would like to analyze a constant epithet of a character's name 'Er Sogotokh, EredelBurudal':

Your name is Orphan child Ogo Tulayakh Of the Middle World, Owner of a foal and Of the batyia made of a rib bone, Your other name is The late-in-life child, The Miserable, The lifelong sufferer, The Lonely Man Er Sogotokh, Eredel, the marksman... (Oyunsky, 2014: 433).

In this example the Yakut common title 'о5о тулаайаax' (lit. Yakut. 'child, orphan') becomes a proper name of the character. It is transferred in English by the means of transcription: Ogo Tulayakh, and literal translation as a comment 'Orphan child':

Let me, Orphan child Ogo Tulayakh Of the Middle world (the italics is used by me - A.N.).

This example of a constant epithet shows that it is necessary to have translation comment in the text. Thus, the nickname of the orphan 'Эр Соготох' (lit. Yakut. 'lonely man') was transcribed as 'Er Sogotokh' and translated literally by the means of translation comment 'Lonely Man'.

A word pair 'эрээйдээх-буруйдаах' was translated from Yakut in three ways: the first one - by the use of the idiom "late-in-life child", the second one by the name of the V. Hugo novel 'Les Miserables', and the last one - by the use of translation comment - 'Life-long sufferer'. Semantics takes the first place in translation of names, not syntactics, so the structure of the word pair is omitted. The reason is that the phenomena of word pairs is not common in the English language, thus, the Yakut word with the meaning of 'miserable', 'poor', 'deprived', and 'suffering' was translated by the words with similar meaning. This method is due to the wide semantic range of the word 'lonely' that includes the meaning of 'miserable' and thus the word 'loneliness' is understood as the orphanage and becomes a synonym of 'deprivation, unhappiness and suffering' in general. The abaahy-woman, who raised the orphan for mercenary purposes, cannot be considered a relative. 
We made an exception for the second element of the word pair 'guilty’ (‘буруйдаах’) that was not translated for objective reasons, because in the Yakut language this element does not have its own semantics and is used only for alliteration. Furthermore, the shift from 'guiltiness' to 'deprivation' is reasonable for the plot: a newborn boy cannot be guilty for his pregnant mother's kidnapping and his birth and upbringing in demon's cave.

Late-in-life child, The Miserable, Life-long sufferer, Lonely Man Er Sogotokh, Eredel, the marksman.

The English full-text translation of P. Oyunsky's olonkho done at NEFU is preceded by a collection of research articles including my Glossary of selected comment. While working on the preservation of exotic elements, we also tried to make the text more intelligible for the English reader, so I made comment as clear as possible so that it made readers understand the Yakut traditions and culturespecific concepts.

Baigal - an ocean. As former steppe nomads the Sakha feel a natural distrust of large water basins and call them 'бай5ал' ((bai 'gal) — the closest equivalentis 'ocean') which has a negative connotation. The spirit of such an ocean is supposed to be only evil (see: abaahy). There is a hypothesis that the name of Lake Baikal derives from this word (Oyunsky, 2014: 1i).

Esekh (e'seh) - a summer solstice festival, in other words the Kumis Festival, usually celebrated 21 June; now modern Sakha celebrate it from the second half of June until the beginning of July. The name derives from theYakut word 'ыс' (es (es)) which means 'sprinkle'. Shamans sprinkle the ground with kumis as a symbol of fertilization and prosperity for good grass growth and healthy cattle (Oyunsky, 2014: lii).

Ilgeh - a milk food or drink of a shining white or yellow colour traditionally symbolizing 1) abundance, favour, benevolence, grace; 2) energy, strength. It is often used as a metaphor for food and richness. Usually liquid, sometimes it has an egg shape (Oyunsky, 2014: lii). Khotun (ho'tun) - a title of an honoured lady; a landlady; a wife. Often it is used together with 'эбэ' (ebeh (ä 'bä)) — 'grandmother'. A flattering addition of these words to geographical names ground (road, mountain, valley, and abyss) or water (river, lake, ocean, swamp) reflects an instinctive fear and respect before the natural forces, e.g. Saidiliki Ebeh Khotun — Saidiliki valley / lake (Oyunsky, 2014: liii). 
Kun Aiyy (Күн Айыы (кјun aj i:)) — a human tribe of descendants of the Upper World who inhabited the Middle World by the order of the supreme deity Urung Aar Toyon. 'Kun' means 'sun', 'sunny', 'solar'; 'Aiyy' - 'god' — highlights the divine origin of these people. They are usually described as 'with the reins on their backs/necks'. 'Reins' symbolize the sunbeams as specific energetic threads (Oyunsky, 2014: liii).

I can include italics as one of the types of translation comment, used as wellproven instrument in highlighting exoticisms, lacunae and culture-specific concepts. In the following abstract there are already mentioned Yakut culture-specific concepts in italics.

I am standing here, In the centre of a wide tuhulgeh, As big as a deep blue lake, Surrounded by a yellow chechir. Today I am praising The sacred white sergeh With seven seleh ropes, For I am seeing My dear golden-chested Skylark, My dear copper-chested Birdy leave... (Oyunsky, 2014: 315).

Italics is a convenient symbol for culture-specific terms, for example, interjections or foreignisms.

'Urui-aikhal! Narin-naskil! Urui-tusku! Kehgel-nushal! Let us praise Akhtar Aiyyhyt, Let us praise Kurye Jehegei, Let us praise Ekhsit Mother Khotun... (Oyunsky, 2014: 315).

There are a limited number of foreign words in the Yakut text of olonkho, except for Mongolic borrowed words such as 'noyon' and 'bogdo' and Russian word 'chervonets' (Yakut. 'чэрбиэнкэ') that was translated by the means of generalization — 'golden coin'.

Yakut. Чэлгиэнэ чэчэтигэр Чэрбиэнкэ көмүс курдук Чэрэлийэ эргийэн...

(Chelgieneh chechitigir Cherbienke kemus kurduk Chereliye ergiyen)

(Oyunsky, 2003: 80) (italics - A.N.).

Literal translation:

Чэлгиэнэ чэчэтигэр — in the open (space, air)

Чэрбиэнкэ көмүс курдук — like pure gold

Чэрэлийэ эргийэн - spinning, glows brightly. 
The Yakut word чэрбиэнкэ originates from the Russian 'chervonets' - a name of the Russian ten-ruble coin. It was unacceptable to use its distorted version in description of a beautiful celestial udagan (sorceress) Aiyy Umsur, so I decided to replace this word with 'golden coin', which was a convenient decision, however, now I see it was possible to use only the comparison 'gold' or 'pure gold'.

Aiyy Umsur udagan oburgu Blazing from the distance Of a one-day-journey, Came out with her fulsome breasts Like a partridge Out of its shelter Out of its open-ended, golden dwelling, Shining bright Like a golden coin Walking around On the spacious side Of her silver Shining yard, Her lips and teeth full of movement as She was busy Saying the following words... (Oyunsky, 2014: 65).

\section{Discussion}

A team of translators was assembled for this project, composed of NEFU teachers and students, specialists of epic poetry, NEFU experts of the Institute of Languages and Cultures of the Peoples of the North-East of Russia, and Yakut translators. Translators shared an unforgettable and unique experience while working on this project. NEFU translators used scientific evidence and defined translation strategies for transferring of the Yakut epic into a foreign language. The relevance of this scientific approach was caused by the lack of theoretic base of such translation and such translation tradition in general. P. Chernykh who translated P. Oyunsky's poem "The Red Shaman" into Russian shows the traditional view on translation from the Yakut language. He says that the language of original text is beautiful but unfortunately, its beauty is lost when translated, because Yakut poetry is based on alliteration and word play (Letter of P. Chernykh-Yakutsky to M. Gorky).

Modern Russian translator and linguist T. Kazakova thinks that translation comment should be considered an additional method accompanying the words translated by the means of any lexical-semantic transformations when, for example, even a dictionary does not provide the vocable or when the term is absent or has another connotation in the translated language (Kazakova, 2001: 113).

As an example, I would like to cite a footnote for the Yakut lexical gap 'suturo' (Yakut. 'cymyрyo') - Hip high fur 'leggings' that was firstly mentioned in song 6 of the English issue of 2014. Apart from the transcription use there was also the use of rather raw translation comment, in which the form, length and function of such clothes was explained quite intelligibly. Certainly, it was only approximate translation, but 
the use of relatively new term in the comment is considered to make the translation understandable.

He slipped a shabby fur coat Over his shoulders, A belt of a willow, Wearing suturo

Loose around the shins, Wearing pants Slipping down from his hips... (Oyunsky, 2014: 261).

This type of clothing is used in literal and metaphorical senses later in other abstracts of the text and is not provided with translation comment, but is highlighted by the italics as an exoticism.

Untied laces Of pants and suturo... (Oyunsky, 2014: 313).

Your deep, lake-wide Squeezing throat With the greediness The size of a suturo lace! (Oyunsky, 2014: 373).

In the English version of the 1st song of Oyunsky's epic, the title of which was translated as 'Oiuunuskay P.A. Njurgun Bootur the Impetuous. The first song', the Yakut translator R. Skrybykin omitted the most Yakut culture-specific concepts and lacunae, because they were not of a significant semantic importance (sic!) in translator's opinion. Skrybykin omitted the common archaism in the original text 'myhaxma' (tuhakh'ta) meaning a round silver piece of jewelry on the woman's hat due to the lack of such term in English. He also omitted the term 'cblкaha' (synga'ha) that means a high-set edge of a yurt, for the same reasons. The units of measure such as 'илии' (i'li:) = a finger (about $1.7 \mathrm{~cm}$.) and 'mymys' (tu'tum) = the height of a clenched fist, were omitted as well, because the translator thought that the units would not have matched the English ones. Skrybykin's translation was published in the 'Vesthik Respublikanskogo kolleja' magazine in 1995. He said that the olonkho had a great number of archaisms whose meanings were only registered in dictionaries and known by only the older generation of the Sakha people. He added that they were untranslatable words that had only emotional colour without any practical meaning (Oiuunuskay, 1995: 4).

This approach is rather controversial and I am going to disagree with it because it is literally the way to agnosticism.

Furthermore, during the preparation period a Yakut researcher asked me not to translate olonkho due to the possibility of revealing the cultural code scripted in the epic text. Thus, principal difficulties of the translation were linguistic and cultural asymmetry, evolving translation from multi-structural languages, cultural 
and translation incompetency, therefore, exaggeration of translation difficulties, and the treatment of olonkho as a sacred text by the Yakut researchers. In this aspect, translation is desacralization of the source text. I also would like to quote R. Jakobson in response to these statements: "All cognitive experience and its classification is conveyable in any language. Whenever there is deficiency, terminology may be qualified and amplified by: loan words, loan translations, neologisms, semantic swifts, circumlocutions" (Jakobson, 1959/2004: 138-143).

Every language has its own perception of objective reality indeed, and translation is one of the human activities aimed to solve of linguistic and cultural conflicts. French linguist G. Mounin thought that translation difficulties caused by cultural differences were feasible. Mounin pointed to relativity of the terms 'translatability' and 'untranslatability'. Translation requires solving linguistic and non-linguistic difficulties and it is achievable to a greater or lesser extent. Communication through a translation is never absolute, but at the same time, is always possible. (Cit. Komissarov, 1999: 37). A. Popovich, while considering cultural aspects of translation, says that interaction between two cultures should be expressed through connotation, not through denotation (Popovich, 1980: 138).

One of the brightest modern researchers J. Mundy looks at the role of the translator and translation practice following Berman and Venuti in examining the foreign element in translation and the 'invisibility' of the translator. Mundy says that the idea is explored that the practice of translation, especially in the English-speaking world, is considered to be a derivative and second-rate activity, and that the prevailing method of translation is 'naturalizing' (Mundy, 2008/2010: 32). A. Berman refers to the use of italics and other non-verbal elements as 'deforming tendencies' of translation: "The destruction of vernacular networks or their exoticization: This relates especially to local speech and language patterns which play an important role in establishing the setting of a novel. There is severe loss if these are erased, yet the traditional solution of exoticizing some of these terms by, for example, the use of italics, isolates them from the co-text. Alternatively, seeking a TL (target language) vernacular or slang is a ridiculous exoticization of the foreign" (Berman, 1985b/2004: 287).

Consequently, according to Berman's understanding of postcolonial theory of translation, italics and other highlighting methods of exoticisms are distorting and corrupting results of colonialism and domination of the prevailing English (Russian) language. This argument is possible, because in translation it is indeed necessary to balance between preservation of ethnic specificity and author's individual style and 
euphonic principle. An excessive use of those may result in disharmony, so the text becomes difficult to read due to the words and terms overload or the text becomes over normalized and undistinguishable from other translated texts. This choice is reasonable in the postcolonial epoch, when translators and publishers for the sake of the dominating language sacrificed the artistic uniqueness of the original text.

There is another view among Asian researchers. Thus, Chang comments on the relativist and post-colonialist view that blames the under-representation from peripheral cultures in international translation studies on Eurocentric biases. ... Radical relativists and post-colonialists in Western translation studies are Eurocentric in their criticisms of non-Western scholars. They are also guilty of 'discipline-centrism', by borrowing theories simplistically from central disciplines to edge out theories indigenous to translation studies itself, thus leading the discipline back to normativism and perpetuating its peripheral position in the humanities (Chang, 2018: 463).

Nevertheless, the common (for the postcolonial epoch) orientation to the source text has a strong influence of L. Venuti's strategy of foreignization. L. Venuti described it through the translation comment of Derrida's lectures, in which he used italics and preserved French terms in parenthesis: "In translating Derrida's lecture I sought to implement his reflections on translation, as well as the concepts and practices that those reflections have inspired in the work of other theorists and translators. This meant adhering as closely as possible to his French, trying to reproduce his syntax, lexicon, and typography by inventing comparable effects - even when they threaten to twist the English into strange new forms" (Venuti, 2004: 423-447).

Modern translation researchers particularly understand the imminence of involuntary loss and necessity of their compensation. Defects in the translation process are results of attempts to prevent text domestication (Lewis, 1985/2004: 262). Furthermore, the translator does not make the final choice; unfortunately, it is publishers who have the final word. K. Seago confirms these concerns, "Translatorial and editorial intervention in the handling of taboo topics or material considered sensitive in the target culture has been well established, especially in the translation of genre literature. These have been discussed in the context of explicit censorship and of self-censorship" (Seago, 2018: 916). In case of translation of the Yakut olonkho I faced British publishers' objections against preservation of the word pairs, a vulgar language register of demons-abaahys, Yakut utensils, biological and other terms and lacunae that were translated by the means of generalization. Subsequently, some constant epithets were reduced due to their 'irrationality', for example, in the source 
text Nurgun Botur's horse has 'a dark stripe on the his black chine', but eventually it was translated as 'black horse'. There were other simplifications made in the translation, e.g. all the word pairs like 'smiling-laughing' and specific collocations considered by publishers as excessive ones were omitted. Thus to more or less extent the expressiveness of the source text was not included in the final variant of the translation.

\section{Conclusion}

In conclusion, I would like to say that it was the first time when NEFU teachers and translators made an English translation of all nine songs of P. Oyunsky's "Nurgun Botur the Swift”. This event was important not only for cultural life of the Yakut people, but for world culture also. This unique heritage of Yakut folk art, delicately preserved by P. Oyunsky, is finally available for the world community. It is unmistakable that the translation will stimulate research interest towards the Yakut epic and folklore not only abroad but in Russia also. What is more, uniqueness of the Yakut epic saga may provide the basis for various books and film scripts.

In the 2014 English translation of the Yakut epic translators oriented to the perception of its future reader unfamiliar with Yakut culture-specific concepts and culture, so they used all possible types of translation comment: intratextual comments, footnotes, and endnotes in the form of a glossary, an introductory article, and additional graphic tools such as italics. The quantity of $2014^{\text {th }}$ edition's comments far outnumbers I. Pukhov's comments on the Russian translation of olonkho. Furthermore, the article and glossary are placed in the beginning of the book to provide the reader basic terms of the Yakut culture and epic traditions before reading. Paraphrasing Thurston, translators of the epic olonkho use various types of comments as localized micronarratives, recognizing an ecosystem of epic genre and suggesting how epic knowledge extends beyond cultural epistemologies (Thurston, 2019: 115).

The footnotes and intratextual comments are used in the translation of the Yakut heroic epic olonkho "Nurgun Botur the Swift" for the first time, even though in the beginning they may slow down the reading process and cause certain losses. At least, translators should do such things deliberately, understanding what and why they are sacrificing. As the world becomes smaller, we learn more about the way people used to live, and thus this problem largely disappears by itself. We can only hope that on the course of human development and geographical expansion of foreign translations the world will learn more about life of people in Yakutia and thus the meaning of a great 
number of terms and culture-specific concepts will be understandable without further explication.

\section{References}

Barkhudarov, L.S. (2008). Yazyk i perevod: Voprosy obshchey $i$ chastnoy teorii perevoda [Language and translation: Questions on translation theory]. Moscow, LKI Publishing House. 240 p.

Berman, A. (1985b/2004). La traduction commeé preuve de l'étranger, Texte 4 (1985): 67-81, translated by L. Venuti as 'Translation and the trials of the foreign'. In L. Venuti (ed.) (2004) The Translation Studies Reader. London and New York: Routledge, 2nd edition, $287 \mathrm{p}$.

Chang, N.F. (2018). Voices from the periphery: further reflections on relativism in translation studies. In Perspectives: Studies in Translation Theory and Practice, 26 (4), 463-477. DOI: 10.1080/0907676X.2018.1443731.

Gak, V.G. (1977). Sravnitel'naya tipologiya frantsuzskogo i russkogo yazykov [Comparative typology of the French and Russian languages]. Leningrad, Prosveshcheniye Publishing House.

Hundayeva, E.O. (2016). Osobennosti perevoda na angliyskiy yazyk buryatskogo geroicheskogo eposa «Gesar» [Peculiarities of the English translation of Buryat heroic epic of King Gesar]. In Cultural Heritage of Traditional Communities in the context of world civilization: problems of translation and intercultural dialogue. Proceedings of the AllRussian Scientific Conference, Yakutsk, November 10-11, NEFU Publishing House, 205 p.

Jakobson, R. (1959/2004). On linguistic aspects of translation. In L. Venuti (ed.) (2004) The Translation Studies Reader, London and New York: Routledge, 2nd edition, $138-143$.

Jansen, H. (2019). I'm a translator and I'm proud: how literary translators view authors and authorship. In Perspectives: Studies in Translation Theory and Practice, 27 (5), 675-688. DOI: 10.1080/0907676X.2018.1530268.

Kazakova, T.A. (2001). Translation Techniques. English - Russian. Practical basis of translation, Saint-Petersburg, Soyuz Publishing House, 113 p.

Komissarov, V.N. (1999). Obshchaya teoriya perevoda [Theory of translation]. Moscow, CheRo Publishing House, 37.

Koptseva, N.P. (2019). Introduction to the thematic issue "topical research in the field of modern social sciences, culture studies and art history”. In Journal of Siberian Federal University — Humanities and Social Sciences, 12 (7), 1130-1131. 
Lewis, P. (1985/2004). The measure of translation effects. In L. Venuti (ed.) (2004) The Translation Studies Reader, London and New York: Routledge, 2nd edition, 262 p.

Mundy, J. (2008/2010). Introducing Translation Studies. Theories and Applications. 2nd ed. Taylor \& Francis Group, 252 p.

Muravyev, V.L. (1975). Leksicheskie lakuny [Linguistic lacunae]. Vladimir, Vladimir State University, 96 p.

Nelyubin, L.L. (2009). Vvedenie v tekhniku perevoda (kognitivno teoretikopragmaticheskiy aspekt) [Introduction to techniques of translation (cognitive and theoretico-pragmatic aspect)]. Moscow, Flinta: Nauka Publishing House.

Oiuunuskay, P.A. (1995). Njurgun Bootur the Impetuous. The first song, translated into English by Ruslan Skrybykin. In Vesthik Respublikanskogo kolleja, (1), Yakutsk, 4.

Oiuunuskay, P.A. (2003). Дьулуруйар Ньургун Боотур [D’uluruyar N’urgun Bootur]. Yakutsk, Bichik Publishing House, 80 p.

Oyunsky, P. (2014). Nurgun Botur the Swift. English translation under the supervision of Alina Nakhodkina, Folkestone, Renaissance Publishing House. 506 p.

Pis'mo P. Chernykh-Yakutskogo k A.M. Gor'komu [The letter of P. ChernykhYakutsky to M. Gorky]. A.S. Pushkin Library Manuscript Collection, Yakutsk.

Popovich, A. (1980). Problemy khudozhestvennogo perevoda [Issues of literary translation], Moscow.

Pukhov, I.V. (2013). Olonkho - drevniy epos yakutov [Olonkho the ancient Yakut epic]. Yakutsk, Saidam Publishing House.

Razumovskaya, V. (2018). Olonkho 'Nurgun Botur the Swift' by Platon Oyunsky as a 'Strong' Text of the Yakut Culture. In Journal of History Culture and Art Research, 7(4), 363. DOI: 10.7596/taksad.v7i4.1858

Seago, K. (2018). Translating violence in crime fiction. In Perspectives: Studies in Translation TheoryandPractice, 26(6),916-929.DOI: 10.1080/0907676X.2017.1407347.

Skugarova, J.V. (2001). K voprosu o vosprijatii inojazychnogo hudozhestvennogo teksta (On perception of the foreign-language literary text). In Vestnik of Moscow State University, Linguistics and intercultural communication, 19 (1), 135-143.

Sulaiman, M.Z., Wilson, R. (2018). Translating tourism promotional materials: a cultural-conceptual model. In Perspectives: Studies in Translation Theory and Practice, 26 (5), 629-645. DOI: 10.1080/0907676X.2018.1437193.

Thurston, T. (2019). The Tibetan Gesar epic beyond its bards: An ecosystem of Genres on the roof of the World. In Journal of American Folklore, 132 (524), 115-136. 
Venuti, L. (2004). The Translation Studies Reader. (ed.) London and New York: Routledge, 2nd edition., 423-447.

Vereshchagin, Y.M., Kostomarov, V.G. (2005). Yazyk i kul'tura [Language and culture]. Moscow, Indrik Publishing House, 1038 p.

\title{
Культура и перевод: переводческие комментарии \\ в английском переводе якутского эпоса олонхо
}

\author{
А.А. Находкина \\ Северо-Восточный федеральный университет \\ им. М.К. Аммосова \\ Россия, 677000, Якутск, ул. Белинского, 58
}

\begin{abstract}
В статье рассматриваются культурологический аспект перевода, проблема переводческого комментария, функиии, типология, причины возникновения. Материалом исследования послужил перевод на английский язык якутского героического эпоса олонхо «Нюргун Боотур Стремительный» П.А. Ойунского (англ. Nurgun Botur the Swift). Aвтор рассматривает понятия "национально-культурный компонент”, “лакуна”, “национальный колорит”, "безэквивалентная лексика" как основные источники возникновения комментариев. Переводческий комментарий является способом передачи и сохранения информаџии, национального своеобразия и эмоционально-экспрессивной функции образа. Переводчик не только выступает в роли интерпретатора текста оригинала, но и достаточно часто выполняет функиию человека, адаптирующего определенные культурные и языковые явления для инокультурной среды. В статье рассмотрены опыт предыдущих изданий якутского эпоса на якутском языке и его переводов на русский и иностранные языки на предмет наличия переводческих комментариев. Уникальность материала и отсутствие разработанной якутско-английской переводческой традиции делают обзор актуальным. Автор предлагает к рассмотрению примеры из английского перевода олонхо, внутритекстовые комментарии, постраничные сноски, затекстовые комментарии и графические средства выделения экзотизмов.

Ключевые слова: культурный, перевод, переводческий комментарий, культурноспецифический концепт, иявет, эпос, олонхо, якутский язык, английский язык, сноска, курсив.
\end{abstract}

Научная специальность: 24.00.00 - культурология. 